\title{
COMPUTER LITERACY AND USE OF ICT AS KEY FACTORS OF MICRO-ENTERPRISE SUCCESS
}

\author{
Borut Werber, Uroš Rajkovič, Marko Urh, Anja Žnidaršič
}

\section{Introduction}

Europe and most of the word is dealing with economy crises and everyone is searching for solutions. Many large companies were destroyed by their own greed and because of their stocks manipulations without solid financial coverage. Because of that also many micro-enterprises have stopped working, but on the other hand more new ones were formed. How to distinct die-hard, high quality, high growth enterprises from low profitable? Why we are interested in micro-enterprises in the first place? Here are some facts and an example that inspired our study.

No generally accepted definition of a microenterprise can be found in the research literature. The most common criterion for a micro-enterprise is the total number of employees, often combined with some financial indicators, such as the firm's annual turnover and assets. In the absence of a precise definition, micro-enterprises are defined in different contexts in various business cultures. Sometimes, the definition of a micro-enterprise depends on the industry [13]. In the USA the definition for small enterprises in most cases is less than 500 employees depending on industry [6]. Industry Canada's definition of a "small business" is a firm that has fewer than 100 employees [9]. On the national front, 78\% of Canada's one million businesses employ fewer than five people. Because of that we must be careful when we compare results between nations. In a research in Slovenia in 1999 [27] the computerisation of small businesses were analysed. From 122 included small firms with 1 to 50 employees, the average number of total employees was only 5.7.

In some studies micro-enterprises are represented only by entrepreneurs. For most readers the notification of entrepreneurship and "the entrepreneur" is so familiar that they need no explanation yet, according to Mills et. al. [18], the concept of entrepreneurship itself remains nebulous, broadly conceived, open to a range of definitions and differently employed. It is hardly surprising that there is no concordant and comprehensive definition of the entrepreneur.

If we know the fact that the number of microenterprises organized as legal and private persons (entrepreneurs) is almost equal (45\% and $55 \%$ ) than we can assume that the whole group needs special attention.

In the last decade European Union (EU) recognized the importance of micro, small and medium-sized enterprises in terms of growth and economic development. On May $6^{\text {th }}, 2003$, the Commission of the European Communities [25] adopted Recommendation 2003/361/EC regarding the definition of micro, small and medium-sized enterprises (SME) in Community policies applied within the Community and the European Economic Area. Within the SME category, a micro-enterprise is defined as an enterprise that employs fewer than 10 persons and whose annual turnover and/or annual balance sheet in total does not exceed EUR 2 million. Slovenia as a member state of EU accepted this recommendation.

In Slovenia, there were 169.360 enterprises registered in $2011 ; 94.5 \%$ of them were microenterprises, $4.1 \%$ were small enterprises, $1.2 \%$ were medium-sized and $0.2 \%$ large enterprises [15]. The overall share of micro-enterprises organized as natural persons (individual private entrepreneurs) was $55.5 \%$ and of legal persons was $44.5 \%$. Most persons were employed in large enterprises $(30.6 \%)$, followed by microenterprises (27.7\%), medium-sized (24.8\%) and small enterprises (16.9\%). Micro-enterprises in 2011 generated around one fifth of the total turnover (19.7\%). Similar share of annual turnover was generated by small $(20.4 \%)$ and middle-size enterprises (26.4\%). 
In Slovenia in 2011, the number of enterprises increased by $2.0 \%$ and turnover by $4.7 \%$. However, the number of persons employed was $2.4 \%$ lower than a year before. The increase in the number of enterprises and the increase in their turnover were mostly recorded in electricity, gas, steam and air conditioning, supply and water supply, sewerage, waste management and remediation activities. The largest decline in the number of employees and the largest decline in their turnover were observed in construction.

How micro can become big we can read in success story [22] about Slovene sewing micro-enterprise Prima, owned by Nataša Pristav. Between September $1^{\text {st }}$ and December $10^{\text {th }}, 2009$, in premises measuring 130 square meters three seamstresses, Pristav herself and her husband sewed numbers for the athletes which were employed at the Olympic and Paralympic Games in Vancouver 2010. Nataša as a former student of University Ljubljana, Faculty for Textile Technology, inherited the family business on her mother's retirement in 1991 and a good reputation allowed her to find a business partner in the large Austrian market. And so, via an agency in Innsbruck with which she has been working for a number of years, she beat off competition from all over the world to win the above order for the Olympic Games in Canada. 'Colours, specifically a dark blue shade that is very difficult to get on a printer, were decisive in the company getting the order,' explains Nataša. What were the success factors in this example? First of all owner of business possesses the knowledge and formal education from textile business she runs. Enterprise is a partner with other enterprises in Austria and is promoted by agency in Innsbruck. How did they find them? Business production is based on a computer supported print and design of textile. To operate such machines computer skills are required. To finish order in time they invested in additional hardware. These and other factors made this firm successful.

Due to the impact of micro-enterprises on economy, recent Slovene statistical data and present legislation, we decided to focus our attention on micro-enterprises and factors related to business success, owner and ICT use as key factors for recognition of perspective micro-enterprises.

\section{Literature Review}

To understand the nature of micro-enterprise we must know their characteristics, more precisely, their organisational characteristics, management, use of strategic planning, use of ICT, owner and employees' characteristics and the environment surrounding the companies. Enterprise characteristics can be according to Levy and Powell [17] described with five stages of development where the first stage of growth is known as Commencement. These organisations have the following characteristics:

- Lack of financial sources for the purchase of ICT, training, etc.

- The corporate strategy can be described as "survival“ and maintaining its position in the competitive environment of the market.

- Limited number of employees.

- Insufficient knowledge of ICT.

- Communication with the customers and suppliers only by e-mail, phone or in writing.

- Information support is by an office software package.

- Failure of the customers to comply with financial obligations.

- Often little specialization of individual associates with everybody doing what is presently needed.

\section{2nd Stage of Growth: Survival}

Enterprises with several years of successful work will reach the ability to cope with all market demands, so they employ more part time or full time employees and are challenged with new organisational problems that demand ICT support. Most of them will in first place hire accounting and bookkeeping service that will support their business process.

\section{3rd Stage of Growth: Successful Position in the Market}

The company is successfully growing and the manager begins to undertake mid-term planning. In this phase of development the further growth of the company significantly depends on the approach of the manager or owner. Using ICT is based on applications such as CAD (Computer Aided Design - software design application), in addition to accounting and other administrative applications. They will tend to integrate electronic shopping and organizational structure into their business model. 


\section{4th stage of Growth: Expansion}

With an increasing number of employees there is a need for the owner to formalize the organisational structure and to delegate responsibility. This group differs from the previous groups of organisations by their higher utilisation of knowledge of their employees. The organisations have defined a corporate and information strategy, they have a hierarchical organisational structure and they need to optimize their processes with information support. They use standard ERP (Enterprise Resource Planning), systems for communication with their partners, so they utilise the electronic exchange of data. In most cases this is the barrier between micro and small business.

\section{5th Stage of Growth: Maturity}

These organisations typically have higher number of employees (80-250), are managed by a team of managers and have hierarchical structure of leadership.

We can conclude that micro-enterprises are mostly in first three stages of growth. Because of that we are certain that micro-enterprises should be studied separately from other sized enterprises. If we try to determine the growth stage of our best practice micro-enterprise Prima, our case from introduction section, we can define it as in the third stage of growth since they used high tech ICT for colouring and cutting of textile and they were a part of an international business networking.

In most cases micro-enterprises work in environment that prevents them progressing and development. Micro-enterprises are negatively affected by the following environment factors [2]:

- Low economic power compared to large companies.

- Difficultly gaining access to capital with a consequently limited ability to finance development activities.

- Worse access to specialized training and education compared to larger companies.

- Lower access to necessary information and consultancy services.

- Unfair competition from large companies and dumping prices of imported products.

- Limited sale of finished products on the domestic market and increased cost of export.
- Competition of retail organisations managed by financially strong companies.

- Weak position in public tenders.

- Failure to and delay in receiving payments resulting in a secondary financial insolvency.

- High administrative demands from government bodies and agencies.

Policy makers often think that creating more start-up companies will transform depressed economic regions, generate innovation, and create jobs [23]. This belief is flawed because the typical start-up is not innovative, creates few jobs, and generates little wealth. Getting economic growth and jobs creation is about encouraging the formation of high quality, high growth companies. Policy makers should stop subsidizing the formation of the typical startup and focus on the subset of businesses with growth potential [23]. In many cases we can find micro-enterprises formed because of saving on human costs. Employees are put in a situation to form their own business and work as subcontractor or they become unemployed. Most of newspaper stands in Slovenia work on this basis. Also employees from repair and service sector from large enterprises such as beer industry become entrepreneurs on the same basis. There are also so called "bypass enterprises" with function to hide financial transactions or to transfer employees from the parent enterprise so that they can downsize. To recognize such micro-enterprises we need factors that form relevant filters.

In research by Hoxha and Capelleras [12] the contribution of fast-growing firms to employment and the determinants of fast growth in Kosovo were analysed. The sample consisted of 585 firm founders. In terms of the firm-related component, the most robust predictor of firm fast growth is the startup size. Results show that smaller firms at startup tend to grow faster than the rest of firms. This is significant for our study because it confirms our assumption that micro-enterprises are an important segment of the fast growing firms. On the other hand, the age of the firm did not show any influence in the firm's fast growth. As the most important factor for fast-growing firms was owner's intention to growth. The drastic changes in size confirm that fast-growing firms experience tremendous organizational changes, furthering managerial complexity, and increasing internal turmoil, challenges that are 
not easy to cope with especially in the short run. Thus, the growth of the firm might not be always desired by the entrepreneurs.

One of possible factors for firm's success is adoption of ICT and its use. In research of Antlova [2] they focused on SME management's approach to ICT, its utilization for competitive advantage and its relation to and defining of business and information strategy. Other aspects of the study looked at the effect of ICT on organizational performance, knowledge and skills of the employees, training and organizational culture. The analysed organizations were divided into five groups according to the level of their development during their business existence. Each group has its specific way of managing the organization, its organizational structure, presence or absence of the corporate strategy, level of utilization of ICT, internal and external integration of ICT supporting processes in the organization and the way of utilization of knowledge of the employees.

In another research of Antlova et al. [3] they identified the most important ICT competencies that influenced a long term growth in the SMEs. They showed that there is no unique competency that would characterize growing or non-growing companies absolutely. It implies that it is always necessary to combine more competencies connected with business and information strategy. The competencies which were connected with information strategy, ICT strategy alignment, business process design and technology analysis resources have the key importance. Therefore they suggest that the managers or owners of SMEs should support educational activities in this area and it is also a challenge for universities to help SMEs to increase their competitiveness with the educational internship.

In research of Burke et al. [5] we found results that show personal characteristic of owner as important for die-hard entrepreneur. For men, inheritance encourages persistence, and facilitates initial self-employment. Having a self-employed father as a role model makes their sons persist longer. Similarly, higher levels of education tend to be associated with entrepreneur persistence among both males and females. However, somewhat surprisingly, early experience of unemployment does not affect the probability of self-employment, while reducing persistence.
In Gill et al. [9] similar factors were analysed. They wanted to extend the findings regarding factors that affect the propensity of small business owners to grow and expand small businesses. A total of 218 Canadian small business owners were surveyed and reported their perceptions of various factors that adversely affect their propensity to grow and expand their businesses. The findings suggest that the factors are perceptions of lack of expertise, family-business role conflict, and lack of management skills. Similarly in the study of Verhuel et al. [26] they have found differences between female and male entrepreneurs. They have found that on average women invest less time in the business than men. This can be attributed to both a lower preference for work time (driven by risk aversion and availability of other income) and a lower productivity per hour worked (due to lower endowments of human, social and financial capital). Productivity of time is positively related to financial capital invested, industry and relevant experience, contact with other entrepreneurs, number of employees, running an existing firm, having separate business premises and the prevalence of outsourcing activities.

The decision-making process is often more intuitive than based on reliable, precise and unambiguous information. In particular, innovative business ideas require people to make decisions based on very little evidence [1], [14]. Small firms generally lag behind medium and large companies in adopting and implementing computerization [16]. This is due to severe constraints on financial resources, lack of in-house expertise, and a short-term management perspective imposed by a volatile competitive environment. The average technical efficiency for large firms is higher than that of SMEs [26]. The estimates on the determinants of technical efficiency show that being a subcontractor has a statistically significant positive influence on SMEs' technical efficiency, but the effect decreases with larger firm size.

In study of Pšeničny and Novak [19] special emphasis was placed on establishing the effect of the factor for dynamic enterprises. As most important was the entrepreneur as holder of the administrative/governance (ownership) and management. Only in the case of a company with over 50 employees, the entrepreneur is required to strengthen the company with professional managers, hire consultants and, 
to a greater extent, include employees in the decision-making and management processes.

The study of Koellinger [14] provides empirical data on the emergence of different types and degrees of entrepreneurial innovativeness. The results suggest that entrepreneurial innovativeness depends on both individual factors and the environment in which the individual lives. In particular, high educational attainment and a high degree of self-confidence are significantly associated with entrepreneurial innovativeness at the individual level.

Steam and Wennberg [24] conducted an empirical study on the effects of research and development (R\&D) on new product development, interfirm alliances and employment growth during the early life course of firms. The effect of initial R\&D on high-tech firm growth is through increasing levels of interfirm alliances in the first post-entry years. $R \& D$ efforts enable the exploitation of external knowledge. Initial R\&D also stimulates new product development later on in the life course of high-tech firms, but this does not seem to affect firm growth. R\&D does not affect the growth rate of new low-tech firms, which seem to be driven mainly by the growth ambitions of the founding entrepreneur. Similar conclusions were found also by Hansen and Hamilton [10] where the owners and managers of the growing firms contrasted from the non-growth firms in their growth ambitions, their optimism and opportunistic strategic thinking. The growing firms were more adaptable, proactive and innovative, particularly towards international market opportunities.

In contrast, micro-enterprises demonstrate a high level of ability to adapt to changes in the environment. They use ICT for automation of existing processes, rather than for decision support, or to increase the flexibility of the firm and thereby gain competitive advantage. While large firms are typically capital and equipment intensive, labour-intensive micro-enterprises may be able to increase productivity and provide value-added services through increased computerization and digitization [16].

Formal and informal networking seems to be one of essential factors for micro-enterprise survival and growth [10]. The owners and managers of the growing businesses were highly networked individuals and emphasized how important this was to success. The most important were private business networks, which were largely formed and developed through involvements in multiple businesses. In research from Watson [27] the association between networking and firm performance for both female and male-controlled SMEs was search for. They results showed little difference in the networks accessed networking by female and male SMEs owners after controlling for education, experience, industry, age and site. The results also indicate that several formal and informal networks are positively associated with firm survival but only formal networks appear to be associated with growth. In particular, accessing an external accountant is associated with survival and growth.

The Internet is gaining commercial viability and is particularly suited to small business, where it enables them to keep doors open 24 hours a day at minimal cost to customers all over the world. With access to increasing markets throughout the world, businesses, including those in rural areas, have a unique opportunity to expand from the traditional and local to the global. Whether a firm trades online with customers or not, however, the internet can give firms the advantage of increased profile in that it can allow companies to present information to potential customers and provide another channel for the purposes of brand building, advertising, and marketing. The intranet could be a very suitable tool for company's internal communication [11]. The range of intranet usage is wide. The intranet can be only a notice board for information but it can also be a full-value communication portal which makes the internal communication process more effective. It should be emphasize that internal communication has a significant impact on company's operations, job performance, and work behaviour and attitudes of employees.

\section{Data Collection and Methodology}

After having reviewed the literature on entrepreneurs, micro, small and SME enterprises, a structured interview framework was developed to help address the research objectives. We decided to use annual turnover as indicator for business success. Because of our previous experiences with micro enterprise owners [30] we offered them too chose among ranges of annual turnover instead to record precise annual turnover. We expected that annual turnover [13], [28] will depend upon characteristic of business [29], [16], [19] characteristics of the 
owner [27], [21], [12], available ICT [20], [2], and level of Internet use [11], [13]. To visualize and define factors we proposed a research model of annual turnover dependency in micro-enterprise illustrated in Figure 1.

Based on this premise, we proposed the following three research questions:
RQ1: Have higher investments in ICT any impact on higher annual turnover?

RQ2: Have characteristics of enterprises (number of workstations, use of local network and similar) any impact on annual turnover?

RQ3: Have characteristics of owners of the enterprises any impact on annual turnover?

\section{Fig. 1: Model of studied factors in dependency with annual turnover}

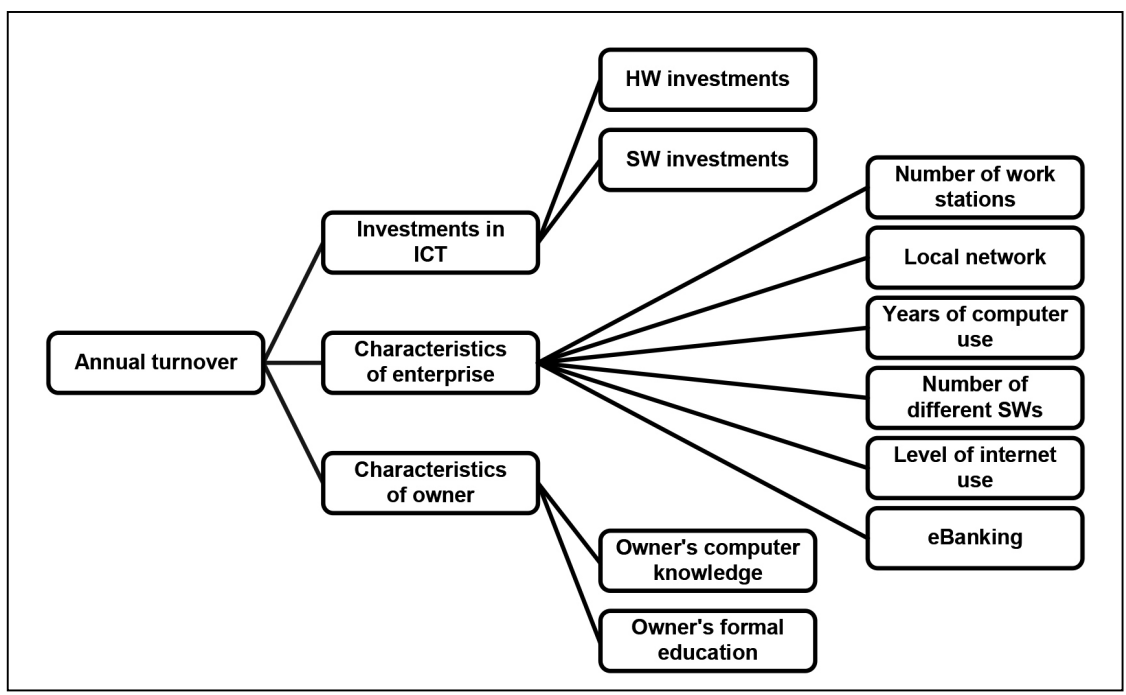

Source: own

According to the 1st research question, we proposed the following two null hypotheses regarding average annual turnover and investments:

HO_1 There is no correlation between average annual HW investments and enterprise annual turnover.

H0_2: There is no correlation between average annual SW investments and enterprise annual turnover.

Null hypotheses H3_0 to H8_0 are set based on the 2 nd research question and combine characteristics of the enterprises with their annual turnover:

H0_3: There are no differences in average number of work stations between groups of enterprises with different annual turnover.
HO_4: There are no differences in annual turnover between enterprises that do or do not use local networks.

H0_5: There is no correlation between time of computer use in years and enterprise annual turnover.

H0_6: There are no differences in different number of used SW among groups of enterprises with different annual turnover.

H0_7: There is no correlation between level of internet use in micro-enterprises and enterprise annual turnover.

H0_8: There are no differences in annual turnover between enterprises that do or do not use eBanking.

Below are two hypotheses based on the 3rd research question referring to characteristics of 
the owner:

H0_9: There are no differences in annual turnover between enterprises with owners that have different formal education.

HO_10: There is no correlation between level of owner's computer knowledge and enterprise annual turnover.

The study was conducted in two stages: the preliminary pilot interviews and the main study. The interview was tested in 36 selected small and micro-enterprises in Slovenia. Repeated contact with respondents helped to improve the accuracy and relevance of the interviews. Interviews were conducted between June and July 2009. Out of the total of 36 interviews, only 16 met the criteria for inclusion in the main study mainly due to the (too big) size of the enterprise.

Data for the main study were collected via structured interviews with owners or top managers of Slovene micro-enterprises between October and December 2009. Several other studies [28], [16], [14] showed that this group plays a dominant role in decision-making process in small enterprises. In the interview mostly closed-response questions were used. Except for demographic data, respondents either rated statements on scale from 1 to 5 , or responded to multiple choice questions. In total, 123 interviews were conducted. Five of them were not usable because the interviewed businesses did not meet the criteria for a microenterprise in different areas (annual turnover, business type etc.), or because of too many questions left unanswered. At the end our sample consisted of $16+118=134$ microenterprises.

For data gathering MS Access database was created with special designed forms to prevent input off incorrect data. Tests were performed using SPSS Statistics version 17.0. The t-test, analysis of variance (ANOVA) and correlations tests were used in hypothesis testing. We found many additional significant factors on second level dependency such as level of internet use depending on owner's formal education, computer knowledge, age etc., but to assure the consistency we didn't use them in our model. Unexpectedly we didn't find annual turnover statistically significantly dependent on a number of employees and/or industry of micro-enterprises.

\section{Results}

\subsection{Characteristics of the Enterprises Participating in the Study}

Respondents came from a wide variety of business backgrounds and sizes. The overall share of individual private entrepreneurs was $56 \%$ and of limited liability companies $40 \%$. Enterprises organized in other organizational forms represented only $4 \%$ of the sample. Among 134 enterprises, $44 \%$ were family owned. The average number of total employees was 3.4, including the owner of the enterprise. In the micro-enterprises analysed three years ago, average number of total employees was 3.2. Based on the data we can conclude that the micro-enterprises in-average employ more employees than three years ago despite of the economic crisis Our results can be confirmed with the statistical data of employment in microenterprises in years 2008, 2009 and 2010 on the website of Statistical Office of Slovenia under the option "Enterprises by activities", where the growth in number of employees among micro-enterprises is also evident. In 2008 there were 217,874 persons employed in micro-enterprises. In 2009 the number increased to 226,638 employed persons and in year 2010 to 227,225 employed by microenterprises [15]. According to data there was $4.3 \%$ growth in number of employees in microenterprises in year 2010 compared to 2008 . To be sure we have checked also the number of micro-enterprises in years 2008 to 2010. It seems that economic crisis hasn't yet been fatal for micro-enterprises because their number is still growing from 142,283 in year 2008 to 156,305 in year 2010. In comparison with small, medium and large enterprises, where the number of businesses and employees is lower from year to year, only in micro-enterprises the numbers are growing. What about annual turnover? We found out that the sum of annual turnover in $€ 1000$ was highest in year 2008 $(18,491,893)$, lowest in year $2009(16,424,546)$ and raised again in year in $2010(17,410,106)$ but was still lower than in 2008. We can assume that this is a result of many new formed microenterprises for self-employment of recently unemployed people from large and medium sized enterprises especially in construction.

The largest share of enterprises in our sample came from service sector (28.4\%), 
manufacturing (13.4\%), construction $(12.7 \%)$ and retail $(10.4 \%)$. Others were from tourism $(8.2 \%)$, servicing and repair $(7.5 \%)$, agriculture $(6.7 \%)$, wholesale $(6.0 \%)$, transportation $(4.5 \%)$ and other $(2.2 \%)$. The average existence time of micro-enterprises was 12.3 years. Most small enterprises $(24.0 \%)$ reported annual turnover (Fig. 2) of between $€ 21,000$ and $€ 68,000$. Annual turnover of more than $€ 209,000$ was reported by $22.4 \%$ of micro-enterprises.

\section{Fig. 2: Micro-enterprises according to annual turnover}

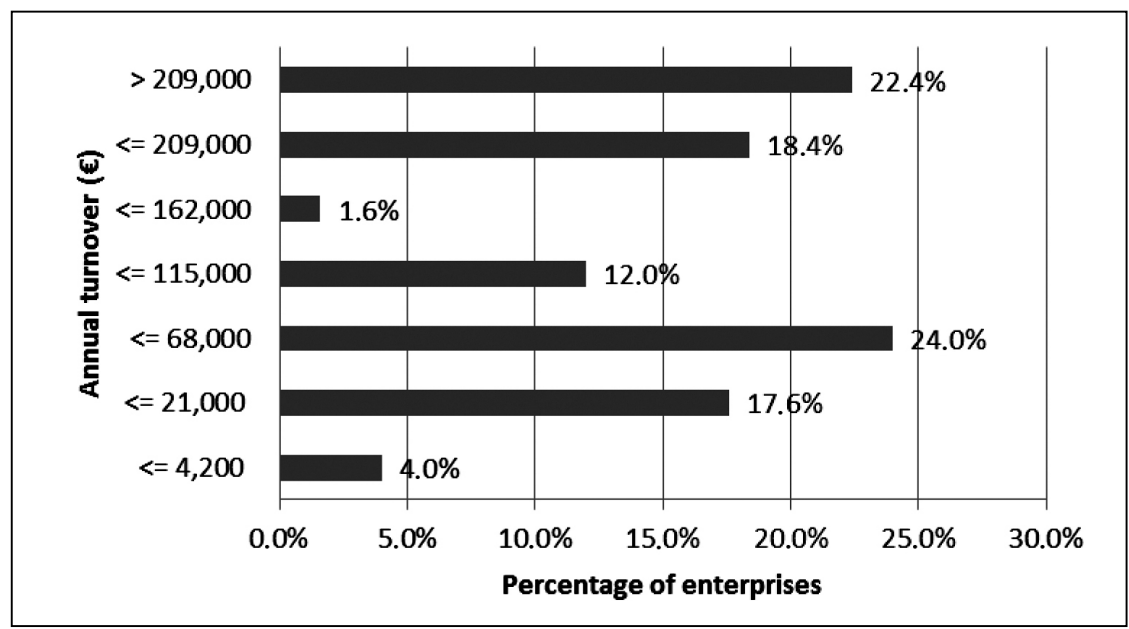

Source: own

The majority of enterprises (76\%) outsourced accounting and bookkeeping to an external partner who is specialized in selling accounting services to small companies.

On average Slovene micro-enterprises use 359 hours of student work per year. The legislation is in favour of hiring students because the taxation and costs are lower in comparison to employment of regular workers. The highest value of student work in analysed micro-enterprise was 6,000 hours per year. This means that in this company they could hire three employees for the entire year. In Slovenia there were 159,986 micro-enterprises with 0 to 9 employees in year 2011. So, theoretically, there were available $57,434,974$ working hours. If we use only half of them, that would represent 27,613 jobs for the entire year, In Slovenia in January 2011 there were 115,132 registered unemployed workers that represent $12.3 \%$ of entire working force. If we add also available working hours in small, medium and large enterprises, the unemployment would be considerably lower.
It is well known that micro-enterprises are similar to small and medium enterprises (SMEs) but on the other hand they have also particular problems in adopting and using ICT in regard to their size. They usually do not have the appropriate skills available in-house and thus have to train existing staff or purchase those skills in the marketplace. When we asked them what kind of formal education has the person in charge of ICT in their business, we were not surprised with the results, although they are rather alarming. Only $7.5 \%$ micro-enterprises in our sample employ somebody with formal computer knowledge. Mainly they were computer engineers, computer technicians or similar. Six percentages of businesses outsources such services. In all other $(86.5 \%)$ of microenterprises ICT depends on employees who do not have a formal education from computer sciences such as economists, commercialists, construction, electro or mechanical technicians. They have also rather exotic employees that are in charge for their ICT field, e.g. cook, hairdresser, auto mechanic and a lawyer. 


\subsection{Characteristics of the Respondents}

The majority of respondents $(76.1 \%)$ were the owners of their businesses, $10.4 \%$ were executive directors, $6.0 \%$ owner-relatives and $7.5 \%$ were some other employees. The age of most of them (44.8\%) was between 31 and 45 years, 33.6\% between 46 and 55, 10.4\% were older than 55 years (Fig. 2). Only 2.2\% were between 21 and 25 and $9.0 \%$ between 26 and 30 years.

There were $71.8 \%$ male and $28.2 \%$ female respondents. We did not find any statistically significant differences between gender and studied factors. There were differences only in the way of information searching. If male owners would search for new information on the internet by themselves or in journals the woman would rather ask somebody (relatives, acquaintances, IT vendors). In most cases, their formal education was secondary school (50.4\%), $12.0 \%$ vocational level, $11.3 \%$ higher, $22.6 \%$ graduate and $3.8 \%$ postgraduate. The majority of respondents (40.3\%) self-estimated their computer knowledge (Fig. 3) as neither good, nor bad. $30.6 \%$ of respondents estimated their computer knowledge as poor or very poor. Most of respondents $(70.7 \%)$ declared that they actively use computer for their work (know how to use business applications), $25.5 \%$ passively uses computer (only for the personal use) and $3.8 \%$ doesn't use computer at all.

\section{Fig. 3: Self-estimated computer knowledge of respondents}

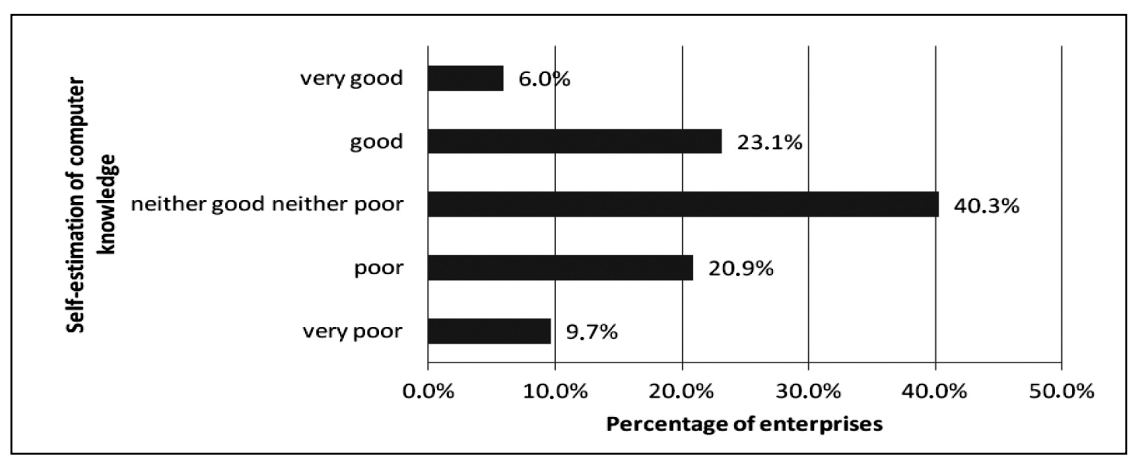

Source: own

\subsection{Computer Hardware and Software}

The average number of laptops per company was 2.6, desktops 1.5, workstations 0.2 and network servers 0.4 . In total, companies from our sample had 4.7 computers per organization (and 1.4 computers per employee). Microenterprises in our sample had on average 8 years and 11 months years of computer experience. On average, micro-enterprises invest $€ 1,538.6$ per year in computer hardware or computer hardware services and 880.4 in software or software licenses. Almost all (98.5\%) of the enterprises had internet connection.

Most enterprises (94.0\%) use some version of the Windows operating system (XP, Vista,
NT). The other $4.5 \%$ of the enterprises use Linux and $1.5 \%$ use SuSe. Figure 4 shows that in $93.3 \%$ of companies general programs (word processor, spreadsheets, databases etc.) were installed, but only a few of them used them to analyse data from their databases or to prepare customized reports. These tools were mostly bought together with the computers, which may explain why they are rarely used. Insufficient computer knowledge and skills of the owners/ managers and employees may be a possible explanation for the non-use of software tools. The relatively low self-assessment of computer knowledge and skills found in our study (Fig. 3) supports this assumption. 


\section{Fig. 4: Type of software used by micro-enterprises}

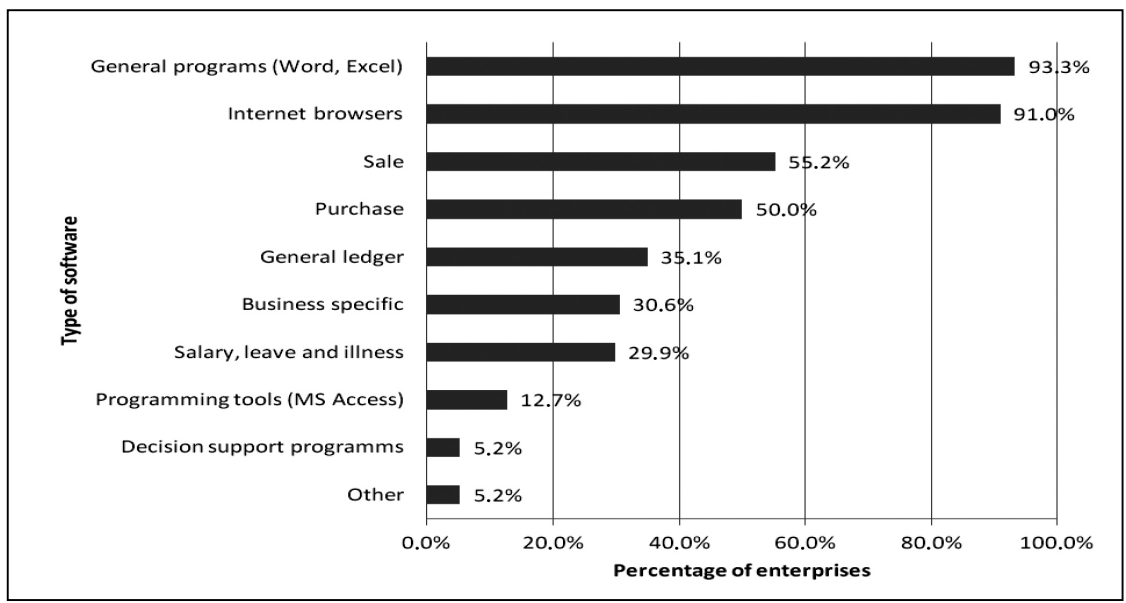

Source: own

Only $12.7 \%$ of businesses used some type of package for application development (MS Access etc.), and 5\% had applications for decision support. Almost half of enterprises $(48.9 \%)$ use some kind of illegal software.

\subsection{Use of Internet}

Almost all enterprises (98.5\%) had internet connection. Not surprisingly, Slovene microenterprises mostly use the Internet for e-mail $(94.0 \%)$, followed by searching for information $(92.5 \%)$ and $78.2 \%$ used internet for electronic banking. Web pages are used in $51.1 \%$ of enterprises for their business advertising (simple hosted web page) and in $36.8 \%$ for advertising of their products and services (their own domain). Internet based business programs are used in $18.8 \%$ of enterprises while $13.5 \%$ of surveyed enterprises offered their customers the possibility to buy products/ services over the Internet.

\subsection{Results of Hypothesis Test}

With an analysis of the data from 134 microenterprises in the sample, we found that:

Correlation between the average annual turnover and average annual HW investments is statistically significantly positive (Pearson correlation coefficient is $0.239, p$-value is 0.007 , and it is significant at $1 \%$ level (Tab. 1); so we can reject the null hypothesis H0_1), which means that enterprises with higher $\mathrm{HW}$ investment also have higher annual turnover.

There exist also statistically significantly positive correlation between the average annual turnover and average annual SW investments (Pearson correlation coefficient is 0.230 , p-value is 0.011 , and it is significant at $5 \%$ level (Tab. 1); so we can reject the null hypothesis H0_2). Therefore we may conclude that enterprises with higher SW investment also have higher annual turnover.

The null hypothesis HO_3 was tested with a t-test where enterprises were divided into two groups (Tab. 2): enterprises with annual turnover lower of higher to $€ 68,000$. There are statistically significant differences in the average number of work stations used in both groups of enterprises with different annual turnover ( $\mathrm{t}=-2,080, \mathrm{p}$-value is $0.040<0.05$; so the null hypothesis $\mathrm{H} 3$ _O can be rejected at $5 \%$ significance level). Enterprises with annual turnover $€ 68,000$ or less have on average 0.06 workstations, while enterprises with annual turnover higher than $€ 68,000$ have in average 0.25 working stations. 
Correlations between annual turnover of enterprises, investments in HW and SW and level of internet use

\begin{tabular}{|c|c|c|c|c|c|}
\hline & & $\begin{array}{l}\text { Annual } \\
\text { turnover }\end{array}$ & $\begin{array}{c}\text { Investments } \\
\text { in HW }\end{array}$ & $\begin{array}{c}\text { Investments } \\
\text { in SW }\end{array}$ & $\begin{array}{c}\text { Level of } \\
\text { internet use }\end{array}$ \\
\hline \multirow{3}{*}{ Annual turnover } & Pearson Correlation & 1 & $.239^{\star *}$ & $.230^{*}$ & $.303^{\star *}$ \\
\hline & Sig. (2-tailed) & & .007 & .011 & .001 \\
\hline & $\mathrm{N}$ & 125 & 125 & 122 & 123 \\
\hline \multirow{3}{*}{ Investments in HW } & Pearson Correlation & $.239^{\star *}$ & 1 & $.361^{* *}$ & $.238^{\star *}$ \\
\hline & Sig. (2-tailed) & .007 & & .000 & .006 \\
\hline & $\mathrm{N}$ & 125 & 133 & 130 & 131 \\
\hline \multirow{3}{*}{ Investments in SW } & Pearson Correlation & $.230^{*}$ & $.361^{\star *}$ & 1 & $.250^{\star \star}$ \\
\hline & Sig. (2-tailed) & .011 & .000 & & .004 \\
\hline & $\mathrm{N}$ & 122 & 130 & 130 & 128 \\
\hline \multirow{3}{*}{$\begin{array}{c}\text { Level of internet } \\
\text { use }\end{array}$} & Pearson Correlation & $.303^{\star \star}$ & $.238^{\star *}$ & $.250^{\star \star}$ & 1 \\
\hline & Sig. (2-tailed) & .001 & .006 & .004 & \\
\hline & $\mathrm{N}$ & 123 & 131 & 128 & 132 \\
\hline
\end{tabular}

** Correlation is significant at the 0.01 level (2-tailed).

* Correlation is significant at the 0.05 level (2-tailed).

Tab. 2:

Descriptive statistics and results of t-test for number of workstations in groups of enterprises with different annual turnover

\begin{tabular}{l|c|c|c|c|c|c|c|c|}
\multirow{2}{*}{} & \multicolumn{4}{|c|}{ Enterprises with annual turnover } & \multicolumn{2}{c}{ t-test } \\
\cline { 2 - 9 } & \multicolumn{4}{|c|}{$€ \mathbf{6 8 , 0 0 0}$ or less } & \multicolumn{2}{c|}{ higher than $€ 68,000$} & \multicolumn{2}{c}{} \\
\cline { 2 - 9 } & $\mathbf{N}$ & Mean & SD & N & Mean & SD & t & p \\
\hline Number of workstations & 54 & 0.06 & 0.302 & 67 & 0.25 & 0.704 & -2.080 & .040 \\
\hline
\end{tabular}

Tab. 3: Descriptive statistics and results of t-test for annual turnover in groups of enterprises with or without local network

\begin{tabular}{|c|c|c|c|c|c|c|c|c|}
\hline & \multicolumn{6}{|c|}{ Use of local network } & \multirow{2}{*}{\multicolumn{2}{|c|}{ t-test }} \\
\hline & \multicolumn{3}{|c|}{ Yes } & \multicolumn{3}{|c|}{ no } & & \\
\hline & $\mathbf{N}$ & Mean & SD & $\mathbf{N}$ & Mean & SD & $\mathbf{t}$ & $\mathbf{p}$ \\
\hline Annual turnover & 39 & $169,412.8$ & $81,543.7$ & 78 & $80,107.7$ & $72,729.6$ & 6.011 & .000 \\
\hline
\end{tabular}

We performed the mean difference test (the t-test) among groups of enterprises that use local networks or not (Tab. 3). We used mean value of classes instead of class number of annual turnover and discovered that there is a statistically significant positive effect of use of local networks on average annual turnover
( $\mathrm{t}=6.011, \mathrm{p}$-value is $0.000<0.01$; so we can reject the null hypothesis $\mathrm{HO}_{-} 4$ at the $1 \%$ significance level). The enterprises that use local networks have on average $€ 169,413$ annually turnover in comparison to those that do not use local networks where on average annually turnover is more than half smaller. 
Tab. 4: Results of correlation between the average annual turnover, owners' computer knowledge and years of computer use

\begin{tabular}{c|c|c|c|c}
\multicolumn{2}{c|}{} & $\begin{array}{c}\text { Annual } \\
\text { turnover }\end{array}$ & $\begin{array}{c}\text { Computer } \\
\text { knowledge }\end{array}$ & $\begin{array}{c}\text { Years of } \\
\text { computer use }\end{array}$ \\
\hline \multirow{4}{*}{\begin{tabular}{c} 
Annual turnover \\
\cline { 2 - 5 }
\end{tabular}} & Pearson Correlation & 1 & $.224^{* *}$ & $.292^{* *}$ \\
\cline { 2 - 5 } & Sig. (2-tailed) & & .009 & .001 \\
\hline \multirow{3}{*}{$\begin{array}{c}\text { Computer } \\
\text { knowledge }\end{array}$} & $\mathrm{N}$ & 133 & 133 & 133 \\
\cline { 2 - 5 } & Pearson Correlation & $.224^{* *}$ & 1 & .095 \\
\cline { 2 - 5 } & Sig. (2-tailed) & .009 & & .273 \\
\hline \multirow{3}{*}{$\begin{array}{c}\text { Years } \\
\text { of computer use }\end{array}$} & $\mathrm{N}$ & 133 & 134 & 134 \\
\cline { 2 - 5 } & Pearson Correlation & $.292^{* *}$ & .095 & 1 \\
\cline { 2 - 5 } & Sig. (2-tailed) & .001 & .273 & \\
\hline
\end{tabular}

** Correlation is significant at the 0.01 level (2-tailed).

${ }^{*}$ Correlation is significant at the 0.05 level (2-tailed).

Correlation between the average annual turnover and years of computer use is statistically significantly positive (Pearson correlation coefficient is $0.229, p$-value is 0.001 (Tab. 4), and it is significant at $1 \%$ level; so we can reject the null hypothesis H0_5), which means that enterprises with longer time of computer use also have higher annual turnover.

The null hypothesis HO_6 was tested with an analysis of variance. Variances among groups of enterprises with different annual turnover are not statistically significantly different (Leven statistic is 1.551, $p$-value is $0.168>0.05$ ), therefore ANOVA can be performed. The results (Tab. 5) showed that there are statistically significant differences in the average number of used SW in groups of enterprises with different annual turnover (ANOVA: $F=4.282, p$-value is $0.001<0.01$; so the null hypothesis H0_6 can be rejected at $1 \%$ significance level). With multiple comparisons (LSD test) we found out that there are statistically significant difference between enterprises with higher annual turnover than $€ 209,000$ and all other categories of enterprises (except for enterprises between $€ 11,500$ and $€ 162,000)$. In general, average annual turnover is higher in businesses with higher number of used SW (which could be confirmed also with Pearson correlation coefficient between a number of different SWs used and annual turnover which is significant at $1 \%$ significance level and is equal to 0.394).

Tab. 5: Descriptive statistics and results of ANOVA for number of used SW in groups of enterprises with different annual turnover

\begin{tabular}{c|c|c|c|c|c}
\multirow{2}{*}{ Annual turnover $(\boldsymbol{\epsilon})$} & \multicolumn{3}{|c|}{ Number of SW } & \multicolumn{2}{c}{ ANOVA } \\
\cline { 2 - 6 } & $\mathbf{N}$ & Mean & SD & F & p \\
\hline$<=4,200$ & 5 & 3.00 & 1.414 & 4.282 & .001 \\
\hline$<=21,000$ & 22 & 3.32 & 1.492 & & \\
\hline$<=68,000$ & 30 & 3.70 & 1.291 & & \\
\hline$<=115,000$ & 15 & 3.73 & 1.223 & & \\
\hline$<=162,000$ & 2 & 3.00 & 1.414 & & \\
\hline$<=209,000$ & 23 & 4.26 & 1.453 & & \\
\hline$>209,000$ & 28 & 5.11 & 1.812 & & \\
\hline
\end{tabular}


Correlation between the class $>$ of annual turnover and level of internet use is statistically significantly positive (Pearson correlation coefficient is $0.303, p$-value is 0.001 , and it is significant at $1 \%$ level (Tab. 1 ); so we can reject the null hypothesis H7_0). Similar to Jungwoo [13] the level of internet use has statistically significant positive effect on annual turnover; higher level of internet use leads to higher annual turnover and vice versa. The above results are supported with representation of average annual turnover in groups of enterprises with different levels of internet use (Tab. 6). The enterprises on second level of internet use (who use internet just for information retrieval) have the lowest annual turnover on average and on the other hand enterprises that use internet for eBusiness have the highest average annual turnover.

\section{Tab. 6: Characteristic of enterprises with different level of Internet use}

\begin{tabular}{l|c|c|c|c|c|c}
\hline \multirow{2}{*}{ Level of Internet use } & \multicolumn{2}{|c|}{ Annual turnover } & \multicolumn{2}{c|}{$\begin{array}{c}\text { Number } \\
\text { of employees }\end{array}$} & \multicolumn{2}{c}{$\begin{array}{c}\text { Owner computer } \\
\text { knowledge }\end{array}$} \\
\cline { 2 - 7 } & Mean (€) & Std. Dev. & Mean & Std. Dev. & Mean & Std. Dev. \\
\hline 1 Information searching & $21,833.3$ & $19,629.9$ & 2.3 & 0.58 & 1.7 & 1.16 \\
\hline 2 Use of e-mail & $57,009.1$ & $65,807.7$ & 3.1 & 1.83 & 2.6 & 1.24 \\
\hline $\begin{array}{l}\text { 3 Simple hosted web } \\
\text { page }\end{array}$ & $45,650.0$ & $36,521.5$ & 1.8 & 0.50 & 2.8 & 0.50 \\
\hline $\begin{array}{l}\text { 4 Advanced web page } \\
\text { with own domain }\end{array}$ & $125,000.0$ & $78,426.4$ & 3.8 & 3.19 & 3.3 & 1.86 \\
\hline 5 eBanking & $112,200.0$ & $88,988.5$ & 3.5 & 2.23 & 2.7 & 0.87 \\
\hline 6 eBusiness & $173,750.0$ & $72,604.9$ & 3.5 & 2.03 & 3.5 & 0.78 \\
\hline $\begin{array}{l}\text { 7 An Internet based } \\
\text { business }\end{array}$ & $128,147.6$ & $91,511.6$ & 3.6 & 2.14 & 3.4 & 0.96 \\
\hline
\end{tabular}

It could be said that use of eBanking divides enterprises among successful and unsuccessful. We have tried to establish if this statement is true for Slovene micro-enterprises. The enterprises report their annual turnover in categories therefore we changed the answers into mid-values of corresponding intervals before the analysis. We used t-test for group comparison ( $t=3.102$, $p$-value is $0.003<0.01$, so we can reject null hypothesis $\mathrm{H} 0 \_8$ at $1 \%$ significance level). There are statistically significant differences (Tab. 7) between enterprises which use eBanking and those which do not in the average annual turnover. Businesses that practice eBanking have on in average $€ 123,539.6$ annual turnover while businesses that do not practice eBanking on average have $€ 73,886.2$ annual turnover.

\begin{tabular}{|c|c|c|c|c|c|c|c|c|}
\hline \multirow[t]{4}{*}{ Tab. 7: } & $\begin{array}{l}\text { ptive } \\
\text { rpris }\end{array}$ & $\begin{array}{l}\text { tatistics } \\
\text { s using } e\end{array}$ & $\begin{array}{l}\text { d results } \\
\text { inking or }\end{array}$ & & t for ann & turnove & group & \\
\hline & \multicolumn{6}{|c|}{ Use of local network } & \multirow{2}{*}{\multicolumn{2}{|c|}{ t-test }} \\
\hline & \multicolumn{3}{|c|}{ No } & \multicolumn{3}{|c|}{ yes } & & \\
\hline & $\mathbf{N}$ & Mean $(€)$ & SD & $\mathbf{N}$ & Mean $(€)$ & SD & $\mathbf{t}$ & $\mathbf{P}$ \\
\hline Annual turnover & 29 & $73,886.2$ & $73,756.3$ & 96 & $12,3539.6$ & $89,149.4$ & -3.020 & .004 \\
\hline
\end{tabular}


If there exist any difference in average annual turnover in groups of enterprises with different owner's level of formal education (the null hypothesis H0_9) was tested with an analysis of variance (Tab. 8). There were no statistically significant differences in variances among groups with different levels of owner's educations (Leven statistic was 0.533 and p-value 0.712) therefore ANOVA is suitable test. We can reject the null hypothesis H0_9 (ANOVA: $F=3.236, p$-value is $0.015<0.05$ ) at the $5 \%$ significance level. Average annual turnover in businesses of lowest formal education level owners is $€ 78,225$, while the average annual turnover in businesses with postgraduate owners is more than double.

\section{Tab. 8: Descriptive statistics and results of ANOVA for average annual turnover in groups of enterprises with different level of owner's education}

\begin{tabular}{c|c|c|c|c|c}
\multirow{2}{*}{ Level of education } & \multicolumn{3}{|c|}{ Annual turnover } & \multicolumn{2}{c}{ ANOVA } \\
\cline { 2 - 6 } & $\mathbf{N}$ & Mean $(\boldsymbol{\epsilon})$ & SD & F & p \\
\hline vocation level & 16 & $78,225.0$ & $83,365.8$ & 3.236 & .015 \\
\hline secondary school & 62 & $100,912.9$ & $85,055.2$ & & \\
\hline higher vocational level & 13 & $90,592.3$ & $88,108.4$ & & \\
\hline graduate & 28 & $150,128.6$ & $84,347.8$ & & \\
\hline postgraduate & 5 & $176,100.0$ & $77,228.9$ & & \\
\hline
\end{tabular}

Source: own

Correlation between the average annual turnover and owners' computer knowledge (Tab. 4) is statistically significantly positive (Pearson correlation coefficient is 0.224 , p-value is 0.009 , and it is significant at $1 \%$ level; so we can reject the null hypothesis HO_10), which means that enterprises with higher owner's computer knowledge also have higher annual turnover. There is also significant positive correlation between years of computer use and average annual turnover of enterprises (Pearson correlation coefficient is 0.292 , $\mathrm{p}$-value is 0.001). Additionally, this result is in accordance with the findings of prior research [6] that the characteristics of decision makers influenced the decision over ICT adoption in $\mathrm{SME}$, even though prior research was focused on team of managers.

\section{Conclusion}

According to our findings in order to take full advantage of the existing technology current owners and managers of micro-enterprises are aware that they should increase the level of their computer skills and knowledge, stay informed about new trends, developments in the ICT and acquire technical and managerial competences needed to effectively manage the IS. Training in using of PC based end-user tools, and their use for data analyses may also help owners, managers and employees of micro-enterprises to gain self-confidence in using ICT, and better exploit the available technology. Because of that investments in education and training are unavoidable.

As concluded in Lee et al. [16], our results also show that it is imperative for microenterprises to adopt computerisation to achieve improvements in business performance. Micro-enterprises in Slovenia are relatively well equipped with ICT (1.4 computers per employee), but they are rather far from exploiting its full potential. Similar to Wiklund et al. [28] and Jungwoo [13], our investigation showed that owner/managers' personal attitudes directly and/or indirectly influence their businesses. Implementation and successful operation of computerised business and achieved annual turnover is strongly related to the characteristics of the owner/manager (formal education, computer knowledge and skills). In case of Kosovo [12] the formal education was less important than the informal knowledge. This implies that specific human capital, gained during operation through specialized trainings, contributes more than formal education to the rapid growth of the firm. Therefore, we can assume that the education gained in 
universities is of that kind that does not offer proper foundation in which entrepreneurs can build their competitive advantage and thus enlarge their businesses as well the extreme conditions for entrepreneurship where formal education plays little role in the fast growth of the firm.

Micro-enterprise owners/managers in general recognise and value ICT, but they use it mainly to support daily operations of the business rather than to support decisionmaking and are mostly not aware of its strategic and organisational impact.

The results in our study confirmed relation between number of used SW and higher annual turnover. We also discovered that investments in HW and SW are in correlation with level of annual turnover. All that indicates that business success also depends on use of ICT.

Entrepreneurs should put efforts in establishing relations with foreign partners, and consider to start the firm in teams rather than individually [12]. The government and Chamber of Commerce and Industry of Slovenia should inspire national and international networking, consult and involve micro-enterprises in business and finance opportunities of EU. They should organize formal and informal education of micro-enterprise owners especially from fields of management and informatics.

Suitable policy interventions from government and active support from the private sector are needed to address the issue. The government needs to take leadership to facilitate a regulatory environment, improve national infrastructure and continue to help with ICT education.

One of the most important factors of microenterprise growth are financial resources. If they cannot finance by themselves they depended on banks that offer high rated credits. If the financial policy in country is not well controlled, a lot of micro-enterprises will be lost because of debts by contracting firms they work for.

Opposite to that also financial support is no guaranty for micro-enterprise success. In research by Bradley et al. [4] they concluded that capital alone is not a 'silver bullet' for the problem of poverty in developing economies. They have shown that, similar to developed nations, innovation is necessary for microcredit businesses to achieve firm performance, which contribute to increases in income and standards of living. They also show that, through innovation, human forms of capital - specifically business expertise and exposure to family business - lead to higher firm performance than financial or social forms of capital.

Finding mechanisms to identify entrepreneurs [18] who are likely to succeed and that help tailor entrepreneurship education and enterprise support to their needs is therefore an important objective, particularly if we are to ensure the optimal use of limited educational and business support resources. A great number of SMEs do not devote any resources to improving their organizational learning process. Furthermore, SMEs often fail to even effectively use publicly subsidized offers of individual lifelong learning programmes for their employees [21]. Firms with entrepreneurial orientation characteristics would focus the attention of individual and departments on promoting mutual learning in which members would remove the ideological package and share knowledge with others.

A Chinese proverb says "Give a man a fish and you feed him for a day. Teach a man to fish and you feed him for a lifetime«. We should learn from this proverb. It is better to teach and inform micro-business owners how and where to earn money, where and how to find new business opportunities and customers, as to lend them the money. The Competitiveness and Innovation Framework Programme (CIP) of European Community [7] with small and medium-sized enterprises (SMEs) as its main target, supports innovation activities (including eco-innovation), provides better access to finance and delivers business support services in the regions. It encourages a better takeup and use of ICT and helps to develop the information society. The CIP runs from 2007 to 2013 with an overall budget of 3,621 million. One of three operational programmes is specially dedicated to ICT use called The Information and Communication Technologies Policy Support Programme (ICT-PSP) and aims at stimulating a wider uptake of innovative ICT based services and the exploitation of digital content across Europe by citizens, governments and businesses, in particular SMEs. The European Commission's eGovernment Action Plan 2011-2015 supports the provision of a new generation of eGovernment services [8]. eGovernment is about using the tools and systems made possible by ICT's to provide better public services to citizens and businesses. 


\section{References}

[1] ANDERSSON, S., FLORE' N, H. Exploring managerial behaviour in small international firm. Journal of Small Business and Enterprise Development. 2008, Vol. 15, Iss. 1, pp. 31-50. ISSN 1462-6004. DOI: 10.1108/14626000810850838.

[2] ANTLOVÁ, K. Motivation and barriers of ICT adoption in small and medium-sized enterprises. E+M Ekonomie a Management. 2009, Vol. 12, Iss. 2, pp. 140-155. ISSN 12123609.

[3] ANTLOVÁ, K., POPELINSKY, L., TANDLER, $J$. Long term growth of SME from the view of ICT competencies and web presentation. $E+M$ Ekonomie a Management. 2011, Vol. 24, Iss. 4, pp. 125-139. ISSN 1212-3609.

[4] BRADLEY, W. S., JEFFERY, S., MCMULLEN, S. J., ARTZ, K., SIMIYU, M. E. Capital Is Not Enough: Innovation in Developing Economies. Journal of Management Studies. 2012, Vol. 49, Iss. 4, pp. 684-717. ISSN 00222380. DOI: 10.1111/j.1467-6486.2012.01043.x. [5] BURKE, E. A., FITZROY, R. F., NOLAN, A. M. What makes a die-hard entrepreneur? Beyond the 'employee or entrepreneur' dichotomy. Small Business Economy. 2008, Vol. 31, Iss. 2, pp. 93-115. ISSN 0921-898X. DOI: 10.1007/s11187-007-9086-6.

[6] CHUANG, T. T., NAKATANI, K., ZHUO, D. An exploratory study of the extent of information technology adoption in SMEs: an application of upper echelon theory. Journal of Enterprise Information Management. 2009, Vol. 22, Iss. $1 / 2$, pp. 183-196. ISSN 1741-0398. DOI: 10.1108/17410390910932821.

[7] EUROPEAN

COMMISSION.

Competitiveness and Innovation Framework Programme (CIP) [online]. European Commission, 2013 [cit. 2013-5-17]. Available from: http://ec.europa.eu/cip/index_en.htm.

[8] EUROPEAN COMMISSION. ICT for public service [online]. European Commission, 2013 [cit. 2013-5-17]. Available from: https:// ec.europa.eu/digital-agenda/en/ict-publicservices.

[9] GILL, A., BIGER, N., MATHUR, N., SHAH, C., BHUTANI, I. Factors That Affect Canadian Propensity To Grow and Expand Small Business. Business and Economics Journal. 2010, Vol. 2010:BEJ.17, pp.1-10. ISSN 21516219.

[10] HANSEN, B., HAMILTON, T. R. Factors distinguishing small firm growers and non- growers. International Small Business Journal. 2011, Vol. 29, Iss. 3, pp. 278-294. ISSN 02662426. DOI: $10.1177 / 0266242610381846$.

[11] HOLÁ, J. Internal communication in the small and medium sized enterprises. $E+M$ Ekonomie a Management. 2012, Vol. 25, Iss. 3, pp. 32-45. ISSN 1212-3609.

[12] HOXHA, D., CAPELLERAS, J. L. Fastgrowing firms in a transitional and extreme environment: are they different? Journal of Small Business and Enterprise Development. 2010, Vol. 17, Iss. 3, pp. 350-370. ISSN 14626004. DOI: $10.1108 / 14626001011068671$.

[13] JUNGWOO, L. Discriminant analysis of technology adoption behaviour: a case of Internet technologies in small businesses. Journal of Computer Information Systems. 2004, Vol. 44, Iss. 4, pp. 57-69. ISSN 0887-4417. [14] KOELLINGER, P. Why are some entrepreneurs more innovative than others? Small Business Economy. 2008, Vol. 31, Iss. 1, pp. 21-37. ISSN 0921-898X. DOI: 10.1007/ s11187-008-9107-0.

[15] KUHELJ, D. Enterprises, Slovenia, 2011 - final data [online]. Statistical office of the Republic of Slovenia, 2011 [cit. 2011-12-23] http://www.stat.si/StatWeb/glavnanavigacija/ podatki/prikazistaronovico? ldNovice $=5151$.

[16] LEE, S. M., KIM, J., CHOI, Y., LEE, S. G. Effects of IT knowledge and media selection on operational performance of small firms. Small Business Economy. 2008, Vol. 32, Iss. 3, pp. 241-257. ISSN 0921-898X. DOI: 10.1007/ s11187-007-9095-5.

[17] LEVY, M., POWELL, P. Strategies for Growth in SMEs. Oxford: Butterworth Heinemann, 2005. ISBN 13978-0-7506-6351-9. [18] MILLS, C., PAWSON, K. Integrating motivation, risk-taking and self-identity: A typology of ICT enterprise development narratives. International Small Business Journal. 2011, Vol. 30, Iss. 5, pp. 584-606. ISSN 0266-2426. DOI: 10.1177/0266242610390594. [19] PŠENIČNY, V., NOVAK, R. Organisational Factors of Rapid Growth of Slovenian Dynamic Enterprises. Organizacija. 2013, Vol. 46, Iss.1, pp. 3-12. ISSN 1581-1832. DOI: 10.2478/orga2013-0001.

[20] RADKEVITCH, U., HECK, E., KOPPIUS, O. Leveraging Offshore IT Outsourcing by SMEs through Online Marketplaces. Journal of Information Technology Case and Application Research. 2006, Vol. 8, Iss. 3, pp. 40-57. ISSN 1522-8053. 
[21] REAL, J., ROLDÁN, J., LEAL, A. From Entrepreneurial Orientation and Learning Orientation to Business Performance: Analysing the Mediating Role of Organizational Learning and the Moderating Effects of Organizational Size. British Journal of Management. 2014, Vol. 25, Iss. 2, pp. 186-208. ISSN 1467-8551.DOI: 10.1111/j.1467-8551.2012.00848.x.

[22] RUBINIĆ, S. Small can be big. Sinfo[online]. April 2010, pp. 20-30 [cit. 2012-12-23]. Available from: http://www.ukom.gov.si/fileadmin/ukom. gov.si/pageuploads/Sinfo/Sinfo_april_final.pdf. ISSN 1854-0805.

[23] SHANE, S. Why encouraging more people to become entrepreneurs is bad public policy. Small Business Economy. 2009, Vol. 33, Iss. 2, pp. 141-149. ISSN 0921-898X. DOI: 10.1007/ s11187-009-9215-5.

[24] STAM, E., WENNBERG, K. The roles of R\&D in new firm growth. Small Business Economy. 2009, Vol. 33, Iss. 1, pp. 77-89. ISSN 0921-898X. DOI: 10.1007/s11187-009-9183-9.

[25] THE COMMISSION OF THE EUROPEAN COMMUNITIES. Commission recommendation of 6 May 2003 concerning the definition of micro, small and mediumsized enterprises. Official Journal of the European Union [online]. 2003, L. 124, [cit. 2012-12-23], pp. 36-41. Available from: http:// eur-lex.europa.eu/LexUriServ/LexUriServ. do? uri=CELEX:32003H0361:EN:HTML. ISSN 1725-2555.

[26] VALKOKARI, K., HELANDER, N. Knowledge management in different types of strategic SMEs network. Management Research News. 2007, Vol. 30, Iss. 7, pp. 597-608. ISSN 0140-9174. DOI: 10.1108/01409170710773724.

[27] WATSON, J. Networking: Gender differences and the association with firm performance. International Small Business
Journal. 2012, Vol. 30, Iss. 5, pp. 536-558. ISSN 0266-2426. DOI: 10.1177/0266242610384888. [28] WIKLUND, J., PATZELT, H., SHEPHERD, D. Building an integrative model of small business growth. Small Business Economy. 2009, Vol. 32, Iss. 4, pp. 351-374. ISSN 0921898X. DOI: 10.1007/s11187-007-9084-8.

[29] YANG, C. H., CHEN, K. Are small firms less efficient? Small Business Economy. 2009, Vol. 32, Iss. 4, pp. 375-395. ISSN 0921-898X. DOI: $10.1007 / \mathrm{s} 11187-007-9082-\mathrm{x}$.

[30] ZUPANČIČ, J., WERBER, B. Key Issues in Information Technology Adoption in Small Companies. In: KIRIKOVA, M., et al. (Eds.). Information Systems Development. Springer, 2002. pp. 353-362. ISBN 978-1-4613-4950-1. DOI: 10.1007/978-1-4615-0167-1_31.

Assist. Prof. Borut Werber, Ph.D. University of Maribor Faculty of Organizational Sciences Department of Informatics borut.werber@fov.uni-mb.si

Assist. Prof. Uroš Rajkovič, Ph.D. University of Maribor

Faculty of Organizational Sciences Department of Informatics uros.rajkovic@fov.uni-mb.si

Marko Urh, Ph.D. University of Maribor Faculty of Organizational Sciences Department of Business and Working Systems marko.urh@fov.uni-mb.si

Anja Žnidaršič, Ph.D.

University of Maribor Faculty of Organizational Sciences Department of Methodology anja.znidarsic@fov.uni-mb.si 


\title{
Abstract
}

\section{COMPUTER LITERACY AND USE OF ICT AS KEY FACTORS OF MICRO- ENTERPRISE SUCCESS}

\author{
Borut Werber, Uroš Rajkovič, Marko Urh, Anja Žnidaršič
}

The objective of this paper is to emphasize issues connected with micro-business financial success and adoption of information and communication technology (ICT) as possible factors to determine further organisational growth. This understanding is based on the results of an investigation conducted in Slovenia between May and December 2009 in 134 Slovene micro-enterprises. Data for the main study were collected via structured interviews with owners or top managers of micro enterprises. We used some demographic questions about the business annual turnover, computerisation, owner's characteristics and some questions about the financial investments in ICT. To visualize and define factors we proposed a research model of annual turnover dependency in micro enterprise. The research focused on characteristics of owners of the enterprise, investments in ICT and characteristics of enterprises' usage of available ICT in correlation to business annual turnover. The results indicate that adoption, the number and type of hardware and software are positively associated with the micro- enterprise success. An important factor is also formal education of the manager and/or owner and his or her computer and ICT knowledge and skills. We also found out that use of internet, eBusiness and number of used business software contribute to enterprise's success. We can confirm that micro-enterprise informatisation can be the basis for a healthy economy growth if adequate knowledge and skills are present. To increase growth in micro-businesses we can use this and additional factors (intentions to growth, size, annual turnover, industry type, ...) as filters to separate potential growing micro-enterprises from others that represent more than $94 \%$ of all enterprises in country. When we defined target group we can start to encourage growth with knowing methods from best practices all over the world. Based on our survey and on the review of literature, recommendations have been given how to be more effective and efficient in encouraging the growth of micro-enterprises.

Key Words: Micro-enterprise, annual turnover, entrepreneurs, usage of information and communication technology.

JEL Classification: 044, M15, C81.

DOI: 10.15240/tul/001/2015-2-012 